\title{
Androprostamines A and $B$, the new anti-prostate cancer agents produced by Streptomyces sp. MK932-CF8
}

\author{
Yohko Yamazaki ${ }^{1}$, Tetsuya Someno ${ }^{1}$, Masayuki Igarashi ${ }^{2}$, Naoko Kinoshita ${ }^{2}$, Masaki Hatano ${ }^{2}$, \\ Manabu Kawada ${ }^{1}$, Isao Momose ${ }^{1}$ and Akio Nomoto ${ }^{1,2}$ \\ Androgen receptor (AR) is a validated target in all clinical states of prostate cancer. Androprostamines A and B, the new \\ inhibitors of androgen receptor, were isolated from Streptomyces sp. MK932-CF8. Their structures were determined by the \\ spectroscopic analysis, degradation studies and synthesis. Androprostamines showed potent inhibitory effect against androgen- \\ dependent growth of human prostate cancer cells without cytotoxicity and repressed the androgen-induced expression of \\ AR-regulated genes.
}

The Journal of Antibiotics (2015) 68, 279-285; doi:10.1038/ja.2014.135; published online 1 October 2014

\section{INTRODUCTION}

Prostate cancer is the most common cancer in western countries and the second leading cause of cancer-related death in men in the United States. ${ }^{1-3}$ In Japan, the incidence of prostate cancer is comparatively low, but is increasing rapidly because of the westernization of dietary habits and the aging of population. Prostate cancer initially occurs as an androgen-dependent tumor, and localized prostate cancers are usually treated with radical prostatectomy or radiation. Furthermore, non-organ-confined prostate cancer responds favorably to androgen ablation therapy. However, prostate cancer progresses from androgendependent to androgen-independent stage and acquires resistance to androgen ablation therapy (called castration-resistant prostate cancer (CRPC) $).{ }^{4}$ CRPC responds poorly to standard cytotoxic regimens and treatment options are limited and palliative.

There are several molecular mechanisms underlying CRPC development including androgen receptor (AR) gene mutation or amplification, altered expression of coregulators and ligand-independent activation of $A R .^{5-8}$ However, importantly, AR still plays an essential role in CRPC. Most CRPC cells still express AR as well as prostatespecific antigen, an androgen-regulated gene and a clinical biomarker for prostate cancer. ${ }^{9,10}$ This is indicating that CRPC cells maintain the AR signaling pathway. AR overexpression is observed in the advanced clinical stage and associate with earlier relapse after radical prostatectomy. ${ }^{11}$ Moreover, in vivo knockdown of the AR results in growth inhibition and regression of CRPC. ${ }^{12}$ Now, it is well established that CRPC is still dependent on AR function. ${ }^{13}$ The antiandrogens bicalutamide and flutamide, widely used in treatment of prostate cancer, act as AR antagonists to prevent androgen stimulation of prostate cancer cells. But despite an impressive initial clinical response, in most cases, the tumor eventually progresses to CRPC in an average of 18 months. ${ }^{14}$

We hypothesized that a new type of inhibitor of AR could serve as a unique therapeutic agent for prostate cancer. To identify a new type of inhibitor of AR, we screened 50000 cultured broths of microorganisms and discovered novel inhibitors of AR function, androprostamines A (1) and B (2) (Figure 1) that showed potent inhibition against androgen-dependent proliferation of human prostate cancer LNCaP and VCaP cells. In this study, we describe the isolation, structure elucidation and biological activity of $\mathbf{1}$ and 2 .

\section{RESULTS AND DISCUSSION}

Taxonomy of the producing strain MK932-CF8

The strain MK932-CF8 formed well-branched substrate mycelia. This strain formed aerial mycelia with bore spirals of 2 to 4 turns (Figure 2). Mature spore chains consisted of 10 to 18 or more spores. The spore was oval with smooth surface and $0.4 \times 0.8-0.5 \times 0.9 \mu \mathrm{m}$ in size. The substrate mycelia were pale yellow to pale brown or pale pink. The aerial mycelia were white to gray. Hygroscopic area was found in the aerial mycelia in 14 to 21 days. These characteristics were observed on yeast extract-malt extract agar (International Streptomyces Project (ISP) medium No. 2), oatmeal agar (ISP medium No. 3), inorganic salts-starch agar (ISP medium No. 4) and glycerolasparagine agar (ISP medium No. 5). The type of diaminopimelic acid isomers in whole-cell hydrolysates of the strain MK932-CF8 was determined to be the LL-form. The partial 16S ribosomal RNA gene sequence (1432 bp, Accession No. for the strain: AB688983) of the strain showed high similarity with those of the genus Streptomyces such as Streptomyces hygroscopicus subsp. glebosus (NBRC $13786^{\mathrm{T}}$, 1424/1436 bp, T: Type strain, 99.1\%), Streptomyces libani subsp. rufus

${ }^{1}$ Institute of Microbial Chemistry (BIKAKEN), Numazu, Numazu-shi, Shizuoka, Japan and ${ }^{2}$ Institute of Microbial Chemistry (BIKAKEN), Tokyo, Shinagawa-ku, Tokyo, Japan Correspondence: Dr I Momose, Institute of Microbial Chemistry (BIKAKEN), Numazu, 18-24 Miyamoto, Numazu-shi, Shizuoka 410-0301, Japan. E-mail: imomose@bikaken.or.jp

Received 25 July 2014; revised 21 August 2014; accepted 29 August 2014; published online 1 October 2014 
<smiles>CC(=O)/C(=C\c1cc(O)c(Cl)c(O)c1)NC(=O)C(NC(=O)CCCCCCN=CCC(=O)N[C@@H](N)C(=O)O)C(C)(C)O</smiles>

Androprostamine A(1)<smiles>CC(C)(O)[C@H](NC(=O)CCCCCCNC(=O)CCC(N)C(=O)N1[CH]C(F)[CH-]C1)C(=O)N/C(=C\c1cc(O)c(Cl)c(O)c1)C(=O)O</smiles>

Androprostamine B (2)<smiles>CC(C)(O)[C@H](NC(=O)CCCCCCN)C(=O)N/C(=C\c1cc(O)c(Cl)c(O)c1)C(=O)O</smiles>

Resormycin

Figure 1 Structures of androprostamine A (1) and B (2) and resormycin.

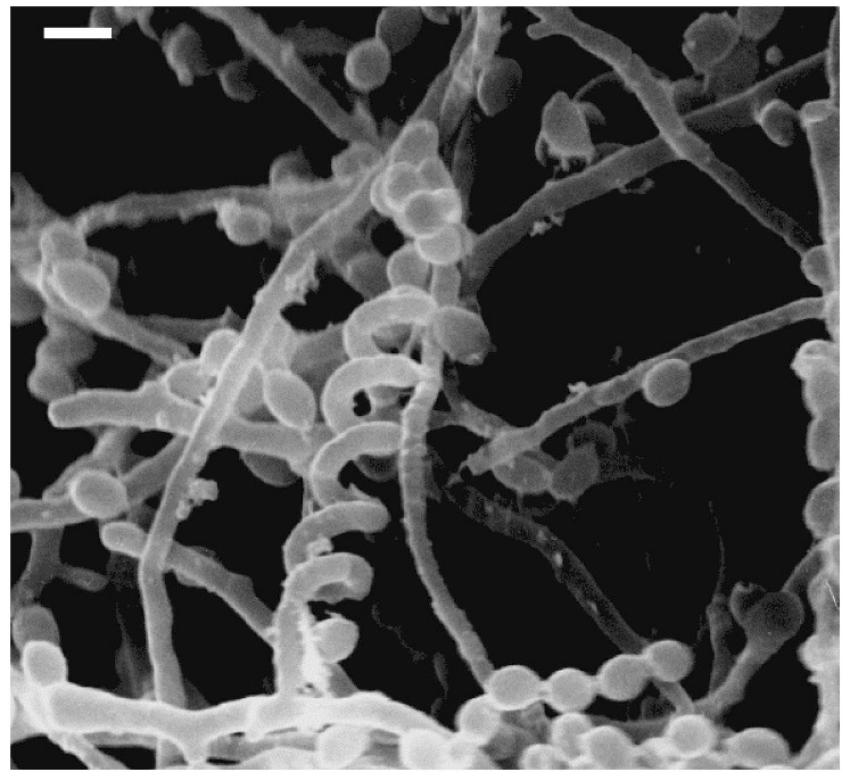

Figure 2 Scanning electron micrograph of strain MK932-CF8 on International Streptomyces Project (ISP) 2 medium for 13 days at $30^{\circ} \mathrm{C}$. Bar $=1 \mu \mathrm{m}$.

(NBRC15424 $\left.{ }^{\mathrm{T}}, 1430 / 1442 \mathrm{bp}, 99.1 \%\right)$ and Streptomyces platensis (NBRC $\left.12901^{\mathrm{T}}, 1429 / 1442 \mathrm{bp}, 99.0 \%\right)$. These phenetic, chemical and genetic analyses of the strain MK932-CF8 suggested that the strain belongs to genus Streptomyces. Therefore, the strain was tentatively designated as Streptomyces sp. MK932-CF8.

\section{Physicochemical properties of androprostamines}

The physicochemical properties of $\mathbf{1}$ and $\mathbf{2}$ are summarized in Table 1. The molecular formulas of $\mathbf{1}$ and 2 are revealed to be $\mathrm{C}_{26} \mathrm{H}_{38} \mathrm{ClN}_{5} \mathrm{O}_{10}$
Table 1 Physicochemical properties of 1 and 2

\begin{tabular}{|c|c|c|}
\hline & 1 & 2 \\
\hline Appearance & White powder & White powder \\
\hline Molecular formula & $\mathrm{C}_{26} \mathrm{H}_{38} \mathrm{ClN}_{5} \mathrm{O}_{10}$ & $\mathrm{C}_{31} \mathrm{H}_{45} \mathrm{CIN}_{6} \mathrm{O}_{11}$ \\
\hline Molecular weight & 615 & 712 \\
\hline \multicolumn{3}{|l|}{ HRESI-MS m/z } \\
\hline \multirow[t]{2}{*}{ Calcd } & 616.2380 (for & 713.2908 (for \\
\hline & $\left.\mathrm{C}_{26} \mathrm{H}_{39} \mathrm{~N}_{5} \mathrm{O}_{10} \mathrm{Cl}\right)$ & $\left.\mathrm{C}_{31} \mathrm{H}_{46} \mathrm{~N}_{6} \mathrm{O}_{11} \mathrm{Cl}\right)$ \\
\hline Found & $616.2386(\mathrm{M}+\mathrm{H})^{+}$ & $713.2903(\mathrm{M}+\mathrm{H})^{+}$ \\
\hline$[\alpha]_{b^{23}}$ & $+76.8($ c 0.1, MeOH $)$ & $+56.8($ c $0.2, \mathrm{MeOH})$ \\
\hline $\begin{array}{l}\text { UV } \lambda_{\max } \mathrm{nm}(\varepsilon) \\
(\mathrm{MeOH})\end{array}$ & $\begin{array}{l}227 \text { (13000, sh), } 289 \\
(11000)\end{array}$ & $\begin{array}{l}227(15100, s h), 289 \\
(12800)\end{array}$ \\
\hline
\end{tabular}

and $\mathrm{C}_{31} \mathrm{H}_{45} \mathrm{ClN}_{6} \mathrm{O}_{11}$ by HRESI-MS and NMR data, respectively. The UV spectra of $\mathbf{1}$ and 2 exhibited a characteristic absorption maximum at $289 \mathrm{~nm}$ in $\mathrm{MeOH}$.

Structure determination of androprostamine A (1)

Most of the ${ }^{1} \mathrm{H}$ and ${ }^{13} \mathrm{C}$ NMR data for 1 were very similar to those of resormycin (Table 2). ${ }^{15}$ The common structures (C-1-C-7") of resormycin and 1 were elucidated by ${ }^{1} \mathrm{H}_{-}{ }^{1} \mathrm{H}$ COSY and heteronuclear multiple bond correlation (HMBC) experiments (Figure 3a). The molecular formula of 1 showed the presence of $\mathrm{C}_{5} \mathrm{H}_{7} \mathrm{NO}_{3}$ unit (C-1"' C-5"') more than that of resormycin. The $\mathrm{C}_{5} \mathrm{H}_{7} \mathrm{NO}_{3}$ unit was assigned to a glutamic acid residue by detailed NMR studies as follows. In the ${ }^{1} \mathrm{H}-{ }^{1} \mathrm{H}$ COSY spectrum, spin networks were observed from a nitrogenbearing methine proton $\left(4^{\prime \prime \prime}-\mathrm{H}\right)$ to methylene protons $\left(2^{\prime \prime \prime}-\mathrm{H}_{2}\right)$ through methylene protons $\left(3^{\prime \prime \prime}-\mathrm{H}_{2}\right)$. In the HMBC spectrum, two

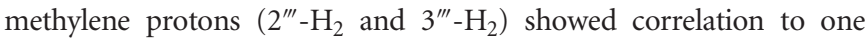
carbonyl carbon $\left(\mathrm{C}-1^{\prime \prime \prime}\right)$. The methine proton $\left(4^{\prime \prime \prime}-\mathrm{H}\right)$ and methylene protons $\left(3^{\prime \prime \prime}-\mathrm{H}_{2}\right)$ showed correlation to another carbonyl carbon $\left(\mathrm{C}-5^{\prime \prime \prime}\right)$, indicating the presence of a glutamic acid moiety. In addition, methylene protons $\left(7^{\prime \prime}-\mathrm{H}_{2}\right)$ also showed correlation to C-1"', indicating that $\gamma$-carboxyl functional group of glutamic acid was connected to amino group $\left(7^{\prime \prime}-\mathrm{NH}\right)$ of resormycin. Thus, the structure of 1 was found to be a glutamic acid derivative of resormycin. The absolute configuration of glutamic acid moiety was determined to be Lconfiguration by the advanced Marfey's method using an acid hydrolysate of 1 (Figure 4a). Furthermore, the structure of 1 was confirmed by synthesis using resormycin as a starting material (Supplementary Figure 1). Resormycin was coupled with Boc-L-Glu (ONSu)-OBu ${ }^{t}$ that was treated with TFA to yield $\mathbf{1}$. The spectroscopic data and physicochemical properties of the synthetic 1 were identical to those of the natural $\mathbf{1}$. Therefore, the absolute configuration of $\mathbf{1}$ was established to be as shown in Figure 1.

Structure determination of androprostamine B (2)

The molecular formula of 2 was determined to be $\mathrm{C}_{31} \mathrm{H}_{45} \mathrm{ClN}_{6} \mathrm{O}_{11}$ based on the HRESI-MS and NMR. By comparing molecular formulas of $\mathbf{1}$ and 2 , it is apparent that $\mathbf{2}$ contained $\mathrm{C}_{5} \mathrm{H}_{7} \mathrm{NO}$ unit more than $\mathbf{1}$. In the ${ }^{1} \mathrm{H}-{ }^{1} \mathrm{H}$ COSY and $\mathrm{HMBC}$ spectrum, the same correlations were observed from the relevant signals $\mathrm{C}-1$ to $\mathrm{C}-5^{\prime \prime \prime}$. Furthermore, chemical shifts except for C-4"', $\mathrm{H}-4^{\prime \prime \prime}$ and $\mathrm{C}-5^{\prime \prime \prime}$ were identical to each other in $\mathbf{1}$ and 2, indicating the presence of common structures from C-1 to C-5"'. Thus, the difference between 1 and 2 was ascribed to the presence of proline residue in 2 based on the following results. In the ${ }^{1} \mathrm{H}-{ }^{1} \mathrm{H}$ COSY spectra, spin networks were observed from a 
Table $2{ }^{1} \mathrm{H}$ and ${ }^{13} \mathrm{C}$ NMR data of 1 and 2

\begin{tabular}{|c|c|c|c|c|c|c|}
\hline & $1^{\mathrm{a}}$ & & $2^{a}$ & & & Resormycin $\mathrm{HCl}$ salt ${ }^{b}$ \\
\hline Position & $\delta_{\mathrm{C}}$ & $\delta_{\mathrm{H}}$ & $\delta_{\mathrm{C}}$ & $\delta_{\mathrm{H}}$ & $\delta_{\mathrm{C}}$ & $\delta_{\mathrm{H}}$ \\
\hline 1 & $174.2 \mathrm{~s}$ & & $170.5 \mathrm{~s}$ & & 166.2 & \\
\hline 2 & $132.6 s$ & & $127.0 \mathrm{~s}$ & & 126.8 & \\
\hline 2-NH & & & & & & 9.42 (1H, br.s) \\
\hline 3 & $133.4 d$ & $7.18(1 \mathrm{H}, \mathrm{s})$ & $139.4 d$ & $7.53(1 \mathrm{H}, \mathrm{s})$ & 130.9 & $6.95(1 \mathrm{H}, \mathrm{s})$ \\
\hline 4 & $136.8 \mathrm{~s}$ & & $135.3 \mathrm{~s}$ & & 132.0 & \\
\hline 5,9 & $111.8 \mathrm{~d}$ & $6.72(2 \mathrm{H}, \mathrm{s})$ & $112.4 d$ & $6.81(2 \mathrm{H}, \mathrm{s})$ & 108.7 & $6.80(2 \mathrm{H}, \mathrm{s})$ \\
\hline 6,8 & $155.5 \mathrm{~s}$ & & $155.6 \mathrm{~s}$ & & 154.1 & \\
\hline 7 & $111.4 \mathrm{~s}$ & & $112.8 \mathrm{~s}$ & & 108.6 & \\
\hline $1^{\prime}$ & $173.3 \mathrm{~s}$ & & $173.9 \mathrm{~s}$ & & 169.8 & \\
\hline $2^{\prime}-\mathrm{NH}$ & $64.4 d$ & $4.49(1 \mathrm{H}, \mathrm{s})$ & $64.1 d$ & $4.55(1 \mathrm{H}, \mathrm{s})$ & 60.5 & $\begin{array}{l}4.52(1 \mathrm{H}, \mathrm{d}, J=9.0 \mathrm{~Hz}) \\
8.54(1 \mathrm{H}, \text { br.d } J=9.0 \mathrm{~Hz})\end{array}$ \\
\hline $3^{\prime}$ & $74.6 s$ & & $74.5 \mathrm{~s}$ & & 71.6 & \\
\hline $4^{\prime}$ & $28.0 q$ & $1.30(3 \mathrm{H}, \mathrm{s})$ & $28.3 q$ & $1.33(3 \mathrm{H}, \mathrm{s})$ & 26.1 & $1.21(3 \mathrm{H}, \mathrm{s})$ \\
\hline $5^{\prime}$ & $28.7 q$ & $1.34(3 \mathrm{H}, \mathrm{s})$ & $28.4 q$ & $1.36(3 \mathrm{H}, \mathrm{s})$ & 27.2 & $1.20(3 \mathrm{H}, \mathrm{s})$ \\
\hline $1^{\prime \prime}$ & $175.0 \mathrm{~s}$ & & 175.0s & & 170.0 & \\
\hline $2^{\prime \prime}$ & $38.8 \mathrm{t}$ & $\begin{array}{l}2.73(1 \mathrm{H}, \mathrm{dd}, J=14.4,6.2 \mathrm{~Hz}) \\
2.78(1 \mathrm{H}, \mathrm{dd}, J=14.4,5.0 \mathrm{~Hz})\end{array}$ & $38.7 \mathrm{t}$ & $\begin{array}{l}2.73(1 \mathrm{H}, \mathrm{dd}, J=14.0,6.0 \mathrm{~Hz}) \\
2.77(1 \mathrm{H}, \mathrm{dd}, J=14.0,5.0 \mathrm{~Hz})\end{array}$ & 37.5 & $\begin{array}{l}2.63(1 \mathrm{H}, \mathrm{dd}, J=15.0,3.0 \mathrm{~Hz}) \\
2.72(1 \mathrm{H}, \mathrm{m})\end{array}$ \\
\hline $\begin{array}{l}3^{\prime \prime} \\
3^{\prime \prime}-\mathrm{NH}_{3}\end{array}$ & $51.8 \mathrm{~d}$ & $3.60(1 \mathrm{H}, \mathrm{m})$ & $51.8 \mathrm{~d}$ & $3.60(1 \mathrm{H}, \mathrm{m})$ & 48.0 & $\begin{array}{l}3.38(1 \mathrm{H}, \mathrm{m}) \\
8.16(3 \mathrm{H}, \mathrm{br} . \mathrm{d}, J=2.5 \mathrm{~Hz})\end{array}$ \\
\hline $4^{\prime \prime}$ & $34.0 t$ & $\begin{array}{l}1.53(1 \mathrm{H}, \mathrm{m}) \\
1.60(1 \mathrm{H}, \mathrm{m})\end{array}$ & $33.9 t$ & $\begin{array}{l}1.49(1 \mathrm{H}, \mathrm{m}) \\
1.58(1 \mathrm{H}, \mathrm{m})\end{array}$ & 31.4 & $\begin{array}{l}1.53(1 \mathrm{H}, \mathrm{m}) \\
1.58(1 \mathrm{H}, \mathrm{m})\end{array}$ \\
\hline $5 "$ & $24.8 \mathrm{t}$ & $1.33(2 \mathrm{H}, \mathrm{m})$ & $24.8 \mathrm{t}$ & $1.30(2 \mathrm{H}, \mathrm{m})$ & 21.4 & $1.41(2 \mathrm{H}, \mathrm{m})$ \\
\hline $6 "$ & $30.7 \mathrm{t}$ & $1.35(2 \mathrm{H}, \mathrm{m})$ & $30.7 \mathrm{t}$ & $1.30(2 \mathrm{H}, \mathrm{m})$ & 26.4 & $1.53(2 \mathrm{H}, \mathrm{m})$ \\
\hline $7^{\prime \prime}$ & $41.8 \mathrm{t}$ & $3.06(2 \mathrm{H}, \mathrm{m})$ & $41.8 \mathrm{t}$ & $3.04(2 \mathrm{H}, \mathrm{m})$ & 38.4 & $2.72(1 \mathrm{H}, \mathrm{m})$ \\
\hline $7^{\prime \prime}-\mathrm{NH}_{3}$ & & & & & & $8.04(3 \mathrm{H}$, br.t, J=3.0 Hz) \\
\hline $1^{\prime \prime \prime}$ & $176.8 \mathrm{~s}$ & & $176.6 \mathrm{~s}$ & & & \\
\hline $2^{\prime \prime \prime}$ & $34.4 \mathrm{t}$ & $2.38(2 \mathrm{H}, \mathrm{m})$ & $33.0 \mathrm{t}$ & $2.46(2 \mathrm{H} . \mathrm{m})$ & & \\
\hline $3^{\prime \prime \prime}$ & $29.4 t$ & $2.12(2 \mathrm{H}, \mathrm{dd}, J=14.4,6.4 \mathrm{~Hz})$ & $28.4 \mathrm{t}$ & $2.18(2 \mathrm{H}, \mathrm{m})$ & & \\
\hline $4^{\prime \prime \prime}$ & $57.0 \mathrm{~d}$ & $3.75(1 \mathrm{H}, \mathrm{t}, J=6.4 \mathrm{~Hz})$ & $53.9 d$ & $4.41(1 \mathrm{H}, \mathrm{t}, J=6.0 \mathrm{~Hz})$ & & \\
\hline $5^{\prime \prime \prime}$ & $177.3 \mathrm{~s}$ & & $170.7 \mathrm{~s}$ & & & \\
\hline $1^{\prime \prime \prime \prime}$ & & & $178.2 \mathrm{~s}$ & & & \\
\hline $2^{\prime \prime \prime \prime}$ & & & $62.5 \mathrm{~d}$ & $4.51(1 \mathrm{H}, \mathrm{m})$ & & \\
\hline $3^{\prime \prime \prime \prime}$ & & & $31.6 \mathrm{t}$ & $2.06(1 \mathrm{H}, \mathrm{m}), 2.35(1 \mathrm{H}, \mathrm{m})$ & & \\
\hline $4^{\prime \prime \prime \prime}$ & & & $27.5 \mathrm{t}$ & $2.04(2 \mathrm{H}, \mathrm{m})$ & & \\
\hline $5^{\prime \prime \prime \prime}$ & & & $50.6 \mathrm{t}$ & $3.64(1 \mathrm{H}, \mathrm{m}), 3.72(1 \mathrm{H}, \mathrm{m})$ & & \\
\hline
\end{tabular}

aNMR spectra were measured in $\mathrm{D}_{2} \mathrm{O}$ solvent.

bNMR spectra were measured in $\left(\mathrm{CD}_{3}\right)_{2} \mathrm{SO}$ solvent. ${ }^{22}$

nitrogen-bearing methine proton $\left(2^{\prime \prime \prime \prime}-\mathrm{H}\right)$ to methylene protons $\left(5^{\prime \prime \prime \prime}-\mathrm{H}_{2}\right)$ through two methylene protons $\left(3^{\prime \prime \prime \prime}-\mathrm{H}_{2}\right.$ and $\left.4^{\prime \prime \prime \prime}-\mathrm{H}_{2}\right)$ (Figure $3 \mathrm{~b})$. In the HMBC spectra, two methylene protons $\left(2^{\prime \prime \prime} '-\mathrm{H}_{2}\right.$ and $\left.3^{\prime \prime \prime \prime}-\mathrm{H}_{2}\right)$ showed correlation to one carbonyl carbon $\left(\mathrm{C}-1^{\prime \prime \prime \prime}\right)$, indicating the presence of a proline moiety. By comparing the NMR spectra of $\mathbf{1}$ and 2, it was suggested that the carboxyl group of proline moiety was connected to $\alpha$-amino group of glutamic acid. Thus, the structure of $\mathbf{2}$ was found to be a proline derivative of $\mathbf{1}$. The absolute configurations of glutamic acid and prolyl moieties were determined to be both L-configuration by the advanced Marfey's method using an acid hydrolysate of $\mathbf{2}$ (Figure $4 \mathrm{~b}$ ). Therefore, the absolute configuration of 2 was established to be as shown in Figure 1.

\section{Biological activities}

Androgen plays a central role in the development and progression of prostate cancer. Human prostate cancer $\mathrm{LNCaP}$ and $\mathrm{VCaP}$ cells maintain androgen sensitivity and can grow androgen dependently. Compounds 1 and 2 inhibited androgen-dependent growth of LNCaP and $\mathrm{VCaP}$ cells similar to resormycin (Figure 5). The treatment of these compounds showed the inhibition of synthetic androgen R1881stimulated growth in LNCaP and $\mathrm{VCaP}$ cells, but exhibited weak cytotoxicity against $10 \%$ fetal bovine serum (FBS)-stimulated growth of LNCaP and VCaP cells. In VCaP cells, these compounds showed stronger cytotoxic activity than in LNCaP cells. Because AR is overexpressed in $\mathrm{VCaP}$ cells, $\mathrm{VCaP}$ cells partially might be able to grow androgen dependently by FBS stimulation. Bicalutamide, the most widely used antiandrogen in the clinic, exhibited selective a

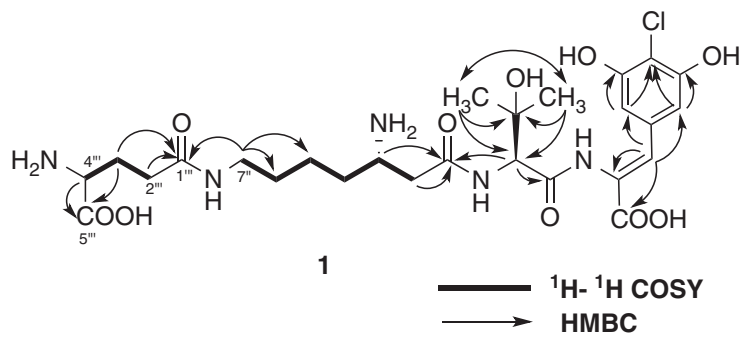

b<smiles>CC(C)(O)[C@H](NC(=O)CCCCCCNC(=O)CCC(NC(=O)[C@H]1CC[C@H]2CC[C@H]1C2)C(=O)O)C(=O)N/C(=C\c1cc(O)c(Cl)c(O)c1)C(=O)O</smiles>

2

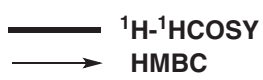

Figure $3 \mathrm{H}-1 \mathrm{H} \mathrm{COSY}$ and heteronuclear multiple bond correlation (HMBC) correlations of $\mathbf{1}$ (a) and 2 (b).

inhibition of androgen-dependent growth of prostate cancer cells. Thus, we found that $\mathbf{1}$ and $\mathbf{2}$ inhibit androgen-dependent growth of LNCaP and VCaP cells like a bicalutamide. ${ }^{16}$

Next, we investigated the effect of $\mathbf{1}$ on the expression of ARregulated genes using real-time PCR. As expected, R1881 treatment 

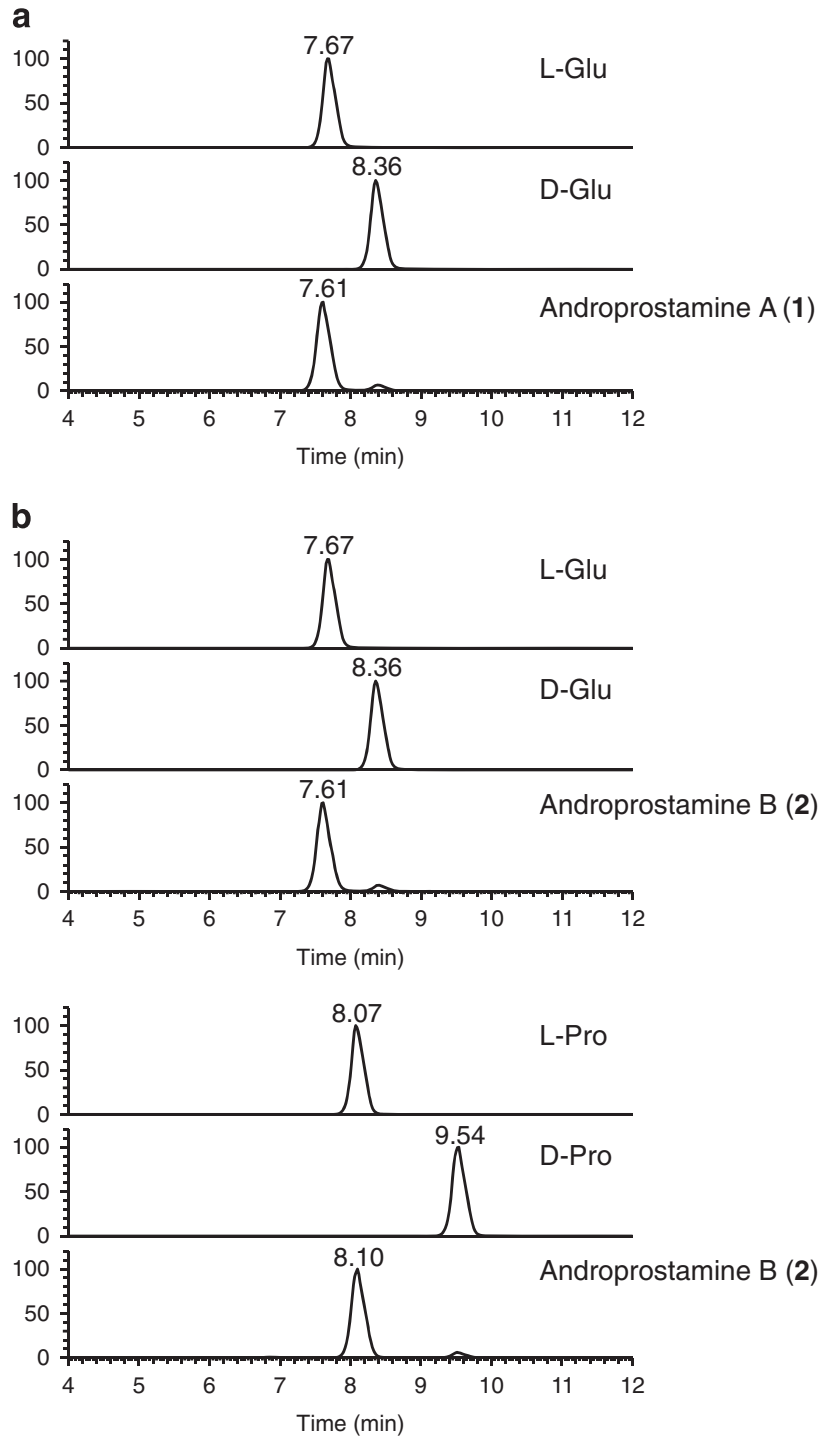

Figure 4 Determination of the stereochemistries of amino acids in $\mathbf{1}$ (a) and 2 (b) by LC-MS analyses. High-resolution extracted-ion chromatogram for glutamic acid derivatives was depicted at $\mathrm{m} / \mathrm{z} 442.1569 \pm 0.0022$ and for proline derivatives at $\mathrm{m} / \mathrm{z} 410.1670 \pm 0.0021$.

dramatically increased the mRNA expression of prostate-specific antigen and TMPRSS2 in LNCaP and VCaP cells. Compound 1 repressed R1881-induced expression of prostate-specific antigen and TMPRSS2 mRNA in LNCaP and VCaP cells at $48 \mathrm{~h}$ of treatment (Figure 6). It is suggested that $\mathbf{1}$ inhibits androgen-dependent growth of prostate cancer cells through the inhibition of AR activity.

Compounds 1 and 2 were isolated from the fermentation broth of Streptomyces sp. MK932-CF8 by the screening system to identify new type of inhibitors of AR. These compounds inhibited androgendependent growth of prostate cancer cells and repressed androgeninduced expression of AR-regulated genes. Although the ability of $\mathbf{1}$ and 2 to bind to the AR was evaluated using recombinant ligandbinding domain of the human $\mathrm{AR}$, these compounds did not bind to ligand-binding domain of AR (data not shown). Therefore, $\mathbf{1}$ and $\mathbf{2}$ are suspected to be not the antagonists for AR, and the action mechanism of $\mathbf{1}$ and $\mathbf{2}$ might be different from the conventional antiandrogens. We are now trying to elucidate the mechanism of $\mathbf{1}$ and $\mathbf{2}$ in detail. AR is a validated target in all clinical states of prostate cancer and there is a possibility that $\mathbf{1}$ and $\mathbf{2}$ act as new anti-prostate cancer agents.

\section{METHODS}

\section{Microorganism}

Androprostamine A (1)- and B (2)-producing strain, MK932-CF8, was isolated from a soil sample collected at Yokohama city, Kanagawa prefecture, Japan. This strain has been deposited in the culture collection of NITE Biological Resource Center (Chiba, Japan) as NITE P-838.

\section{Taxonomic studies}

Morphological characteristics of the spores and mycelia were observed with a scanning electron microscope (Hitachi S-570, Tokyo, Japan). Cultural and physiological characteristics were determined by the methods of Shirlig and Gottlieb $^{17}$ and Waksman. ${ }^{18}$ The substrate and aerial mycelium color including soluble pigments were assigned by the Color Harmony Manual, 1958 (Container Corporation of America, Chicago, IL, USA). The isomer of 2,6diaminopimelic acid in the cell wall was analyzed by the method of Becker et al. ${ }^{19}$ and Staneck and Roberts. ${ }^{20}$ The $16 \mathrm{~S}$ rRNAs were examined by the method reported previously. ${ }^{21}$

\section{Analytical measurement}

Optical rotations were measured on a JASCO P-1030 polarimeter (Tokyo, Japan). UV spectra were recorded on a Hitachi U-2910 spectrometer. ${ }^{1} \mathrm{H}$ and ${ }^{13} \mathrm{C}$ NMR spectra were measured on a JEOL JNM ECA 600 spectrometer (Tokyo, Japan) using TMS as an internal standard. HRESI-MS spectra were measured with JEOL JMS-T100LC, Thermo Fisher Scientific LTQ Orbitrap XL and Q Exactive hybrid quadrupole-Orbitrap mass spectrometers (San Jose, CA, USA).

\section{Fermentation}

Streptomyces sp. MK932-CF8 was cultured by two methods. The liquid culture was performed to produce resormycin ${ }^{15,22}$ and androprostamine $\mathrm{A}$, and the solid culture was performed to produce androprostamines A and B.

The liquid culture was carried out as described below. A slant culture of Streptomyces sp. MK932-CF8 was inoculated into a 500-ml baffled Erlenmeyer flask containing $110 \mathrm{ml}$ of a seed medium consisting of $2.0 \%$ galactose, $2.0 \%$ dextrin, $1.0 \%$ Bacto Soytone (enzymatic digest of soybean meal; Becton, Dickinson and Company, Franklin Lakes, NJ, USA), 0.5\% corn steep liquor (by-product of the corn wet-milling process; Kougo Starch, Chiba, Japan), $0.2 \%$ ammonium sulfate and $0.2 \% \mathrm{CaCO}_{3}$ in deionized water $(\mathrm{pH} 7.4$ before sterilization). The culture was incubated on a rotary shaker (180 r.p.m.) at $27^{\circ}$ C for 3 days. Aliquots of $3 \mathrm{ml}$ of this seed culture were transferred into $500 \mathrm{ml}$ rotary flasks containing $110 \mathrm{ml}$ of the production medium composed of $2 \%$ starch, $2 \%$ glucose, $0.5 \%$ dried yeast extract (Nihon Pharmaceutical, Tokyo, Japan) and $0.2 \% \mathrm{CaCO}_{3}$ in deionized water ( $\mathrm{pH} 7.2$ before sterilization), and cultured for 12 days at $27^{\circ} \mathrm{C}$.

The solid culture was carried out as described below. The seed culture was performed by using a same method as the liquid culture. Aliquots of $70 \mathrm{ml}$ of the seed culture were transferred into $2100 \mathrm{ml}$ stainless steel vats, each of which contained $150 \mathrm{~g}$ rolled barley and $250 \mathrm{ml}$ deionized water as a solid production medium. The culture was incubated at $30^{\circ} \mathrm{C}$ for 14 days by static culture. After incubation, the fermented solid medium (10 stainless steel vats) was extracted with $400 \mathrm{ml}$ of ethanol and extracted with $400 \mathrm{ml}$ of $70 \%$ aqueous ethanol once again.

\section{Isolation of androprostamines A (1) and B (2)}

The total ethanol extract $(8000 \mathrm{ml})$ was filtered and evaporated to remove ethanol. The aqueous solution was applied to a Diaion HP-20 column (Mitsubishi Chemical, Tokyo, Japan) that was washed with deionized water and then eluted with $50 \%$ aqueous acetone. After concentration of the active fractions to remove acetone, it was passed through the Amberlite CG 50 resin column $\left(\mathrm{NH}_{4}{ }^{+}\right.$form, Dow Chemical, Midland, MI, USA). The active fractions were applied on a TOYOPEARL HW-40 column (Tosoh, Tokyo, Japan) and eluted with deionized water. Then, the active fractions were concentrated under reduced pressure to yield oily material. The material was dissolved in $50 \%$ 

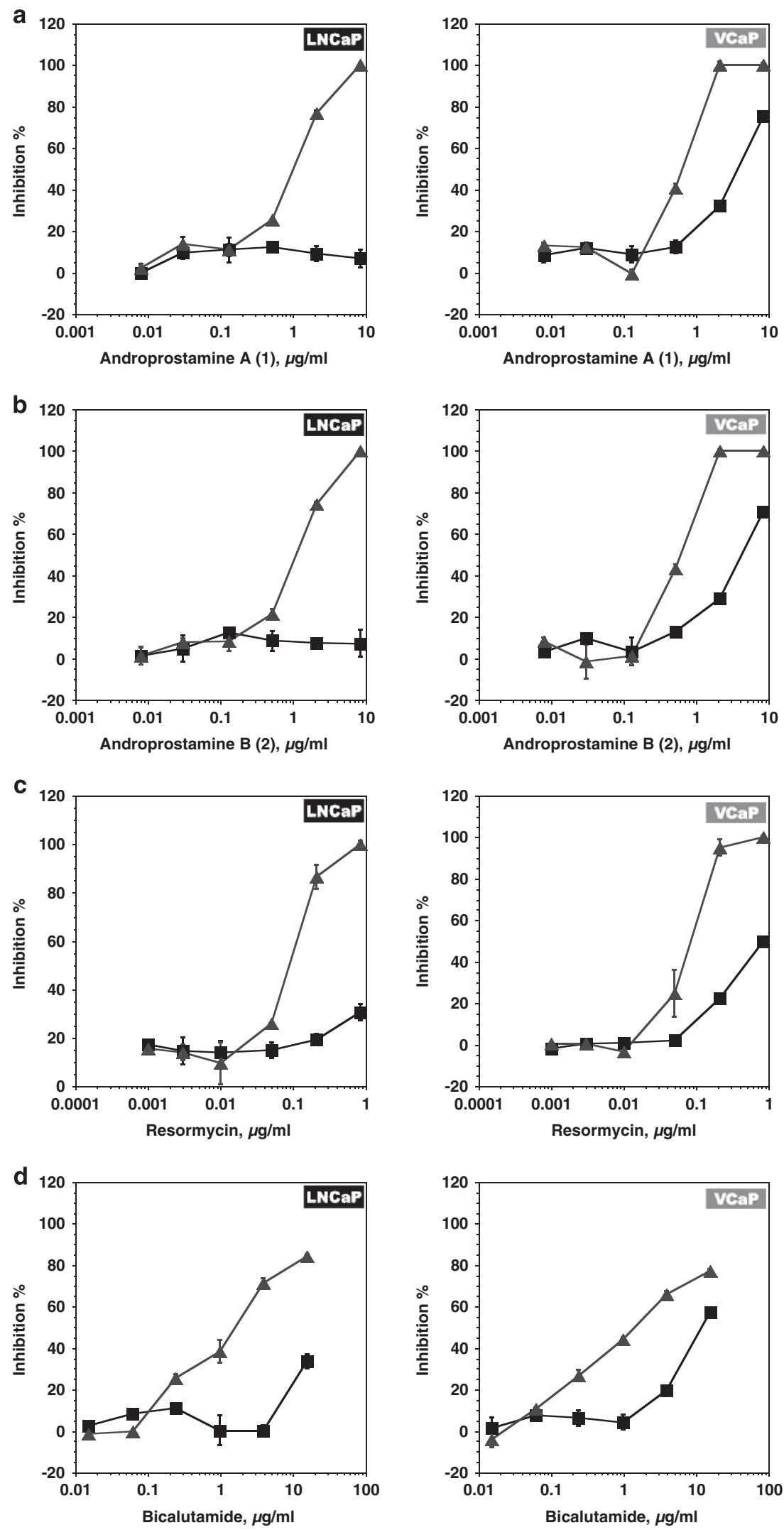

Figure 5 Inhibition of androgen-dependent growth of LNCaP and VCaP prostate cancer cells by $\mathbf{1}$ (a), $\mathbf{2}$ (b), resormycin (c) and bicalutamide (d). cytotoxicity; $\boldsymbol{\Delta}$, inhibition of androgen-dependent growth. Data represent the mean \pm s.d. of at least three independent experiments performed in triplicate. 
a

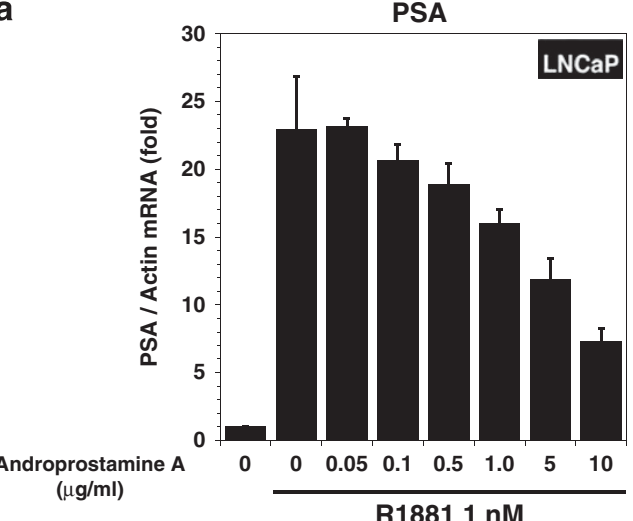

b

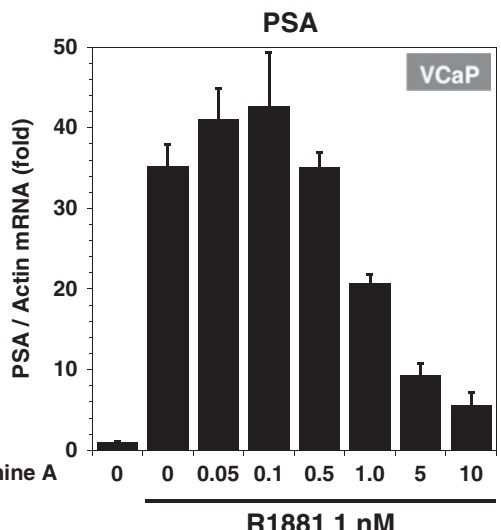

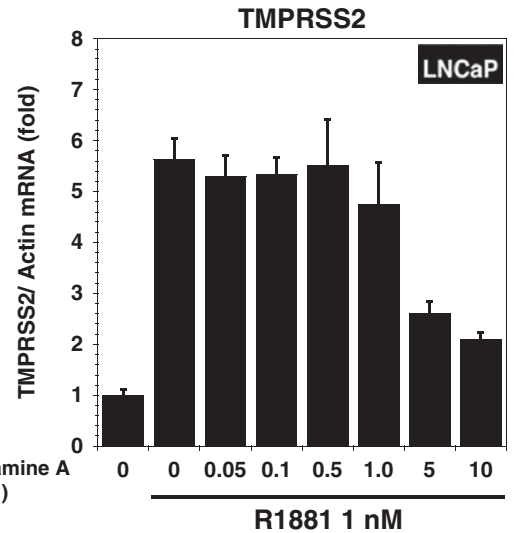

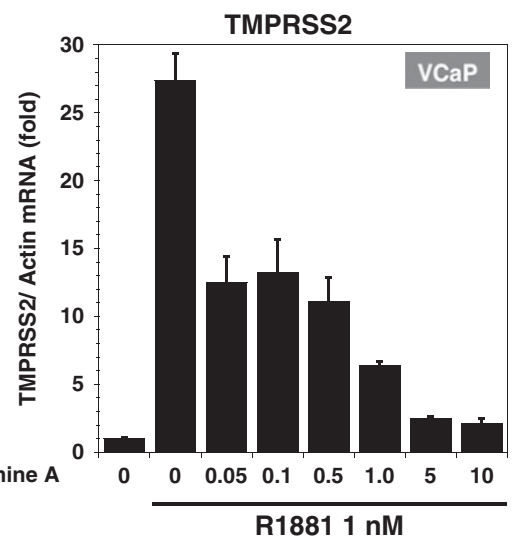

Figure 6 Inhibition of androgen receptor (AR)-mediated expression of prostate-specific antigen (PSA) and TMPRSS2 mRNA in LNCaP (a) and VCaP (b) prostate cancer cells by 1 . LNCaP and VCaP cells were treated with $1 \mathrm{~nm}$ of R1881 and the indicated concentration of 1 . After $48 \mathrm{~h}$, PSA and TMPRSS2 mRNA were measured by real-time PCR. Values were normalized to actin gene expression and expressed relative to the control sample. Data represent the mean \pm s.d. of at least three independent experiments performed in triplicate.

aqueous methanol and applied on a Sephadex LH-20 column (GE Healthcare, Little Chalfont, UK) and eluted with 50\% aqueous methanol. The fractions containing androprostamines $(87.2 \mathrm{mg})$ were further purified by HPLC (Capcell Pak $\mathrm{C}_{18}$ UG, Shiseido, Tokyo, Japan, $20 \times 250 \mathrm{~mm}$; solvent, $10 \%$ acetonitrile containing $0.5 \% \mathrm{TFA}$; detection, $\mathrm{UV}$ at $300 \mathrm{~nm}$; flow rate, 10

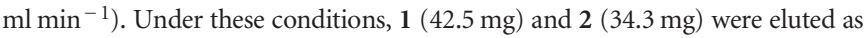
peaks with retention time of 21 and $43 \mathrm{~min}$, respectively. Furthermore, they were dissolved in a small amount of $50 \%$ aqueous methanol and applied on a LH-20 column and eluted with 50\% aqueous methanol, respectively. The active fractions were concentrated under reduced pressure to give pure compounds 1 $(18.1 \mathrm{mg})$ and $2(11.8 \mathrm{mg})$ as white powders, respectively. Resormycin was isolated from the liquid culture broth according to previous procedure. ${ }^{22}$

\section{Determination of $\mathrm{D} / \mathrm{L}$-configuration of amino acids}

The stereochemistry of glutamic acid and proline moieties in androprostamines was determined by the advanced Marfey's method. ${ }^{23,24}$ Androprostamines $(0.1 \mathrm{mg})$ were hydrolyzed with $0.5 \mathrm{ml}$ of $6 \mathrm{M} \mathrm{HCl}$ at $110^{\circ} \mathrm{C}$ for $24 \mathrm{~h}$. The reaction mixture was concentrated under reduced pressure to dryness, and the resulting residue was dissolved in $50 \mu \mathrm{l}$ of water. Subsequently, $20 \mu \mathrm{l}$ of $1 \mathrm{M}$ $\mathrm{NaHCO}_{3}$ and $100 \mu \mathrm{l}$ of $1 \%$ 1-fluoro-2,4-dinitrophenyl-5-L-leucineamide (L-FDLA) were added to the solution, and the reaction mixture was incubated at $37^{\circ} \mathrm{C}$ for $1 \mathrm{~h}$. After quenching by the addition of $20 \mu \mathrm{l}$ of $1 \mathrm{M} \mathrm{HCl}, 100 \mu \mathrm{l}$ of the resulting solution was diluted with $900 \mu \mathrm{l}$ of $50 \%$ aqueous acetonitrile to prepare the sample for LC-MS analyses. Authentic samples (L-FDLA derivatives of both stereoisomers of glutamic acid and proline) were prepared according to the same procedure. The LC-MS analyses were performed under the following conditions: column; Capcell Pak $\mathrm{C}_{18}$ UG120 $(3 \mu \mathrm{m}, 2.0 \mathrm{~mm} \times 50 \mathrm{~mm}$, Shiseido), flow rate; $0.3 \mathrm{ml} \mathrm{min}^{-1}$, mobile phase; linear gradient elution with aqueous acetonitrile containing $0.1 \%$ formic acid (acetonitrile, 20-60\%, $20 \mathrm{~min}$ ), mass spectrometer; positive ion mode, detection; $\mathrm{m} / \mathrm{z}$ $442.1569 \pm 0.0022$ for glutamic acid and $m / z$ 410.1670 \pm 0.0021 for proline.

\section{Synthesis of 1}

To a solution of resormycin hydrochloride $(100 \mathrm{mg}, 0.18 \mathrm{mmol})$ in $4 \mathrm{ml}$ of 1,4dioxane- $\mathrm{H}_{2} \mathrm{O}(1: 1)$ was added $\mathrm{Et}_{3} \mathrm{~N}(55.1 \mu \mathrm{l}, 0.39 \mathrm{mmol})$ and Boc-L-Glu $(\mathrm{ONSu})-\mathrm{OBu}^{t}(78.8 \mathrm{mg}, 0.20 \mathrm{mmol})$. The mixture was stirred for $2 \mathrm{~h}$ at room temperature, and concentrated in vacuo. The residue was dissolved in $2 \mathrm{ml}$ of TFA and stirred for $1 \mathrm{~h}$ at room temperature. The resulting mixture was washed with diethyl ether and concentrated in vacuo. A portion of crude material was chromatographed on a preparative HPLC (Capcell Pak $\mathrm{C}_{18}$ UG, Shiseido, $20 \times 250 \mathrm{~mm}$; solvent, $10 \%$ acetonitrile containing $0.5 \%$ TFA; detection, UV at $300 \mathrm{~nm}$; flow rate, $10 \mathrm{ml} \mathrm{min}^{-1}$ ). The desired fractions were collected, and concentrated to a small volume, and chromatographed on a column of Sephadex LH-20 that was developed with 50\% aqueous $\mathrm{MeOH}$. The desired fractions were collected and concentrated to give $1(52.1 \mathrm{mg})$ as a white powder. The spectroscopic data and physicochemical properties of the synthetic compound 1 were identical to those of the natural 1 . The optical rotation of synthetic 1 was $[\alpha]_{\mathrm{D}}^{20}+84.0(c 0.12, \mathrm{MeOH})$.

\section{Cell culture}

Human prostate cancer cell lines, LNCaP and VCaP, were purchased from ATCC (Manassas, VA, USA). LNCaP cells were cultured at $37^{\circ} \mathrm{C}$ under $5 \%$ $\mathrm{CO}_{2}$ in PRMI 1640 medium (Nissui, Tokyo, Japan) supplemented with $10 \%$ FBS (MP Biomedicals, Strasbourg, France), $0.3 \mathrm{mg} \mathrm{ml}^{-1}$ glutamine, $100000 \mathrm{Ul}^{-1}$ penicillin $\mathrm{G}$ and $100 \mathrm{mgl}^{-1}$ streptomycin. VCaP cells were cultured at $37^{\circ} \mathrm{C}$ under $5 \% \mathrm{CO}_{2}$ in Dulbecco's modified Eagle's medium 
(Nissui) supplemented with 10\% FBS (Sigma, St Louis, MO, USA), 100 $000 \mathrm{Ul}^{-1}$ penicillin $\mathrm{G}$ and $100 \mathrm{mgl}^{-1}$ streptomycin.

\section{Determination of androgen-dependent growth of prostate cancer cells}

LNCaP and VCaP cells were cultured in phenol-red-free RPMI-1640 medium (Life Technologies, San Jose, CA, USA) supplemented with $2 \%$ charcoalstripped FBS for 1 day, and treated with the samples and $1 \mathrm{~nm}$ R1881, a synthetic androgen (Waterstonetech, Carmel, IN, USA), for 5 days. For cytotoxicity assay, $\mathrm{LNCaP}$ and $\mathrm{VCaP}$ cells were cultured in phenol-red-free RPMI-1640 medium supplemented with 2\% charcoal-stripped FBS for 1 day, and treated with the samples and 10\% FBS for 5 days. The cell viability was determined by MTT assay and shown as percentage of untreated controls.

\section{RNA isolation and real-time PCR}

LNCaP and VCaP cells were cultured in RPMI-1640 medium supplemented with 2\% charcoal-stripped FBS for 1 day, and treated with $1 \mathrm{~nm}$ R1881 and various concentrations of androprostamine A for $48 \mathrm{~h}$. Total RNA was isolated from LNCaP and VCaP cells using an RNeasy plus kit (Qiagen, Hilden, Germany), according to the manufacturer's standard protocol. Complementary DNA synthesis was carried out using the Reverse Transcription System (Promega, Madison, WI, USA) according to the manufacturer's standard protocol. Quantitative real-time PCR was performed on a Thermal Cycler Dice Real Time System (Takara, Shiga, Japan) using SYBR Premix Ex Taq II (Takara). All the primers were purchased from Takara. Values were normalized to actin gene expression and expressed relative to the control sample.

\section{ACKNOWLEDGEMENTS}

We thank Dr R Sawa, Ms Y Kubota and Mr S Ohba for the spectral measurements. This paper is dedicated to the memory of Ms Naoko Kinoshita, who suddenly passed away in 2012 .

1 Jemal, A., Siegel, R., Xu, J., Ward, E. Cancer statistics, 2010. CA Cancer J. Clin. 60, 277-300 (2010).

2 American Cancer Society. Cancer Facts \& Figures 2008, (American Cancer Society: Atlanta (GA), (2008).

3 Jemal, A. et al. Cancer statistics, 2009. CA Cancer J. Clin. 59, 225-249 (2009)

4 Shen, M. M., Abate-Shen, C. Molecular genetics of prostate cancer: new prospects for old challenges. Genes Dev. 24, 1967-2000 (2010).
5 Koivisto, P. et al. Androgen receptor gene amplification: a possible molecular mechanism for androgen deprivation therapy failure in prostate cancer. Cancer Res. 57, 314-319 (1997).

6 Taplin, M. E. et al. Androgen receptor mutations in androgen-independent prostate cancer: Cancer and Leukemia Group B Study 9663. J. Clin. Oncol. 21, 2673-2678 (2003).

7 Heinlein, C. A., Chang, C. Androgen receptor (AR) coregulators: an overview. Endocr. Rev. 23, 175-200 (2002).

8 Rennie, P. S., Nelson, C. C. Epigenetic mechanisms for progression of prostate cancer. Cancer Metastasis Rev. 17, 401-409 (1998).

9 Dorkin, T. J., Neal, D.E. Basic science aspects of prostate cancer. Semin. Cancer Biol. 8, 21-27 (1997).

10 Arnold, J. T., Isaacs, J. T. Mechanisms involved in the progression of androgenindependent prostate cancers: it is not only the cancer cell's fault. Endocr. Relat. Cancer 9, 61-73 (2002).

11 Henshall, S. M. et al. Altered expression of androgen receptor in the malignant epithelium and adjacent stroma is associated with early relapse in prostate cancer. Cancer Res. 61, 423-427 (2001).

12 Snoek, R. et al. In vivo knockdown of the androgen receptor results in growth inhibition and regression of well-established, castration-resistant prostate tumors. Clin. Cancer Res. 15, 39-47 (2009).

13 ChenC. D. et al. Molecular determinants of resistance to antiandrogen therapy. Nat. Med. 10, 33-39 (2004).

14 Lam, J. S., Leppert, J. T., Vemulapalli, S. N., Shvarts, O., Belldegrun, A. S. Secondary hormonal therapy for advanced prostate cancer. J. Urol. 175, 27-34 (2006).

15 Igarashi, M., Nakamura, H., Naganawa, H., Takeuchi, T. Resormycin, a novel herbicidal and antifungal antibiotic produced by a strain of Streptomyces platensis. II. Structure elucidation of resormycin. J. Antibiot. 50, 1026-1031 (1997).

16 Rathkopf, D., Scher, H. I. Androgen receptor antagonists in castration-resistant prostate cancer. Cancer J. 19, 43-49 (2013).

17 Shirlig, E. B., Gottlieb, D. Methods for characterization of Streptomyces species. Int. J. Syst. Bacteriol. 16, 313-340 (1966).

18 Waksman, S. A. The Actinomycetes Vol. II, 1-363 (The Williams \& Wilkins: Baltimore, 1961)

19 Becker, B., Lechevalier, M. P., Gordon, R. E., Lechevalier, H. A. Rapid differentiation between Nocardia and Streptomyces by paper chromatography of whole-cell hydrolysates. Appl. Microbiol. 12, 421-423 (1964).

20 Staneck, J. L., Roberts, G. D. Simplified approach to identification of aerobic actinomycetes by thin-layer chromatography. Appl. Microbiol. 28, 226-231 (1974) .

21 Hamada, M. et al. Streptomyces kasugaensis sp. nov.: a new species of genus Streptomyces. Actinomycetologica 9, 27-36 (1995).

22 Igarashi, M. et al. Resormycin, a novel herbicidal and antifungal antibiotic produced by a strain of Streptomyces platensis. I. Taxonomy, production, isolation and biological properties. J. Antibiot. 50, 1020-1025 (1997).

23 Fujii, $\mathrm{K}$. et al. A nonempirical method using LC/MS for determination of the absolute configuration of constituent amino acids in a peptide: elucidation of limitations of Marfey's method and of its separation mechanism. Anal. Chem. 69, 3346-3352 (1997).

24 Fujii, K., Ikai, Y., Oka, H., Suzuki, M., Harada, K. A nonempirical method using LC/MS for determination of the absolute configuration of constituent amino acids in a peptide: combination of Marfey's method with mass spectrometry and its practical application. Anal. Chem. 69, 5146-5151 (1997).

Supplementary Information accompanies the paper on The Journal of Antibiotics website (http://www.nature.com/ja) 